University of Nebraska - Lincoln

DigitalCommons@University of Nebraska - Lincoln

Contemporary Issues in Educational Leadership Educational Administration, Department of

2020

\title{
Lifelong Effects of Poverty
}

Jill McCaslin-Timmons

Marilyn Grady

Follow this and additional works at: https://digitalcommons.unl.edu/ciel

Part of the Educational Administration and Supervision Commons, Educational Leadership Commons, and the Education Economics Commons

This Article is brought to you for free and open access by the Educational Administration, Department of at DigitalCommons@University of Nebraska - Lincoln. It has been accepted for inclusion in Contemporary Issues in Educational Leadership by an authorized administrator of DigitalCommons@University of Nebraska - Lincoln. 
Contemporary Issues in Educational Leadership, 2:2 (2020)

ISSN 2472-9744; http://digitalcommons.unl.edu/ciel/

Copyright (c) 2020 Jill McCaslin-Timmons \& Marilyn L. Grady

doi 10.32873/unl.dc.ciel.1013

\title{
Lifelong Effects of Poverty
}

\author{
Jill McCaslin-Timmons, Ph.D. \\ Fairbury Public Schools \\ jillat@hotmail.com \\ Marilyn L. Grady, Ph.D. \\ University of Nebraska-Lincoln \\ mgrady1@unl.edu
}

\begin{abstract}
Poverty in the United States affects children in public schools. In reviewing the poverty literature, the following themes emerged the struggle to define poverty in the United States, characteristics of families in poverty, the impact of poverty on school performance, and the lifelong effects of poverty on children.

A personal story of a public school administrator who grew up in poverty is part of the report. The impact of the experiences of poverty continue to affect the way the individual thinks about poverty and interacts with families who experience poverty.
\end{abstract}

\section{Lifelong Effects of Poverty}

The purposes of this paper are to (a) present literature on poverty from different points of view, and (b) to examine these resources in relation to the experiences of one individual who lived in poverty as a child. 


\section{Literature on Poverty}

In reviewing the poverty literature, several themes emerged. The themes included the struggle to define poverty in the United States, characteristics of families in poverty, the impact of poverty on school and the lifelong effects of poverty on children. In the following section, a synopsis of three books and two articles that address poverty are presented.

Each of the authors mentioned the difficulty in defining poverty. In Iceland's book, Poverty in America, he explained that finding agreement on a definition of poverty has proven to be difficult (2013). He stated, "Although poverty is a concrete phenomenon for those who live it, what people judge to constitute poverty varies across both time and place." He further explained that the "views of poverty reflect social conditions" (p. 12). The United States government also struggled to measure poverty and the official measure was adopted in 1969 (p. 22). Although most people recognize the need to update the official poverty measure, agreement on what constitutes poverty is difficult to reach. For example, Rector and Johnson (2004) wrote that the living conditions of "poor" in America were overall not that bad. They explained, "the typical American defined as poor by the government has a car, air conditioning, a refrigerator, a stove, a clothes washer and dryer, and a microwave" (p. 1). After describing the possessions that poor people in America had, they noted, "While this individual's life is not opulent, it is equally far from the popular images of dire poverty" (p. 1). Boteach and Cooper, in What You Need When You're Poor (2011), explained that in 2008, half of all poor households with children indicated, "there were days when they didn't know how or if they could pay for their next meal." They reported that the Heritage Foundation over focused on household amenities and were missing a real understanding of what it is like for a poor family. They wrote

the Heritage Foundation craftily creates indexes that rank households on skewed measures of 'amenities' that suggest that no further federal action is needed to buoy the standard of living of poor and working-class families. Such indexes 
are heartless and foolish. Heartless because they ignore the fact that it takes much more than a few appliances to support a family. (Boteach \& Cooper, 2011)

Iceland defined poverty as referring to "economic, or income, deprivation" (2013, p. 23). He identified two basic types of poverty measures, absolute and relative. Absolute measures, "typically attempt to define a truly basic-absolute-needs standard and therefore remain constant over time" (p. 23). This is similar to the measure the U.S. uses for defining poverty. Relative measures, which are used more commonly in Europe than the U.S., "define poverty as a condition of comparative disadvantage, to be assessed against some relative, comparative disadvantage, to be assessed against some relative, shifting, or evolving standard of living" (p. 23) The key difference between the two is how they are updated, or not, over time. Absolute poverty is constant, relative poverty changes as standards of living change.

In the book, Teaching with Poverty in Mind, Jensen (2009), acknowledged the difficulty with defining poverty. He defined poverty as, a "chronic and debilitating condition that results from multiple adverse synergistic risk factors and affects the mind, body and soul" (p. 6).

Jensen (2009) described six different types of poverty and the characteristics of each. The first, situational poverty, is, "caused by a sudden crisis or loss and is often temporary" (p. 6). Generational poverty is, "occurring in families where at least two generations have been born into poverty" (p. 6). Absolute poverty, which "involves a scarcity of such necessities as shelter, running water, and food” (p. 6). Relative poverty is refers, "to the economic status of a family whose income is insufficient to meet its society's average standard of living” (p. 6). Urban poverty occurs in areas with 50,000 people or more; and, rural poverty occurs in areas where populations are under 50,000.

The second theme that emerged from the literature were the common characteristics of families in poverty. Lareau, author of Unequal Childhoods (2013, completed a study of white and black families who were middle class, working class, and poor families. She found several consistent characteristics of families living in poverty. First, she discovered that children from working class or poor families were less likely to 
be involved in structured, extracurricular activities. When they did participate in those activities, it tended to be fewer activities than the children of higher socioeconomic status did. Not surprisingly, Lareau also discovered that the neighborhoods and life experiences differed between low income/poor and higher income families. The students in lower/ poor income families had experienced a great deal more violence than those from higher socioeconomic families.

Lareau (2013) noted the difference in the way the families communicated. She noticed repeatedly that the lower income families were more likely to use directives versus reasoning with their children. She noted that, "Working-class and poor children ... often have more 'childlike' lives, with autonomy from adults and control over their extended leisure time" (p. 3). This was in contrast to the middle class children who are often more engaged in structured activities in their 'leisure time.'

Lareau (2013) noted that students learned to interact with authority figures differently. Whereas middle class children learned to shake hands and look people in the eyes, poor families may not look each other in the eye when conversing. Lareau pointed out that middle class children were taught, 'the rules of the game' that govern interactions with institutional representatives" (p. 6). In other words, they learned how to work within the system and how to reason and negotiate so that they could make the system work for them. On the other hand, children from the working class and poor were less likely to understand the "rules of the game" and did not differ their interactions to try to make the system work for them. Instead, they were more likely to accept, "the actions of persons in authority" (p. 6).

Lareau (2013) also reported the differences in the understanding of financial matters in the poor or working class versus middle class families. She noted that in lower income families, the children were often aware of the difficulties and that "money matters were frequently discussed" (p. 35).

In addition, Lareau (2013) stated that the children of poor or working class lives were more, "relaxed and, more importantly, the pace of life was slower" (p. 35). This is in contrast to the more commonly structured activities of children in middle class families. There were occasions where children of lower income families wanted to be involved in 
organized, extracurricular activities, but due to transportation or cost issues, they could not or could do so only on a very limited basis.

Lareau (2013) observed that in lower income families, when children began to show more interest or skills for a certain activity, this was less recognized and in fact, these interests were treated as "inconsequential" (p. 36). She stated there were more frequent amounts of free time when: they watched more television, or played more with relatives or friends. She described this as "more of a separation between adults' worlds and children's worlds” (p. 36).

Jensen (2009) reported similar information. He wrote that poor children are, "disproportionately exposed to adverse social and physical environments" (p. 8). In other words, they are more likely to have negative experiences because of the low-income neighborhoods in which they live. Some of the negative experiences included, "greater traffic, higher crime rates, less playground safety ... less ... green space” (p. 8). He described children of poverty as having, "fewer and less-supportive networks than their more affluent counterparts so; they live in neighborhoods that are lower in social capital; and as adolescents, are more likely to rely on peers than on adults for social and emotional supports." $\mathrm{He}$ reported that children of poverty are more likely to live in "chaotic, unstable households" and they are more likely to have difficulty establishing "rewarding friendships" with children their own age and often have more "stress-ridden attachments with parents, teachers and adult caregivers" (pp. 8-9).

Other characteristics Jensen (2009) described as common in families living in poverty were, "depression, chemical dependence, and hectic work schedules." As a result, attachments that form with parents are not as healthy leading to children often feeling, "isolated and unloved, feelings that kick off a downward spiral of unhappy life events, including poor academic performance, behavioral problems, dropping out of school, and drug abuse" (p. 9). The consequence of these experiences often resulted in a lack of college options and a continued life of poverty.

Jensen (2009) addressed the experiences that students of poverty face that are rarely faced by students whose families are more affluent. "Children raised in poverty rarely choose to behave differently, but they are faced daily with overwhelming challenges that affluent children 
never have to confront, and their brains have adapted to suboptimal conditions in ways that undermine good school performance" (p. 14). He explained that students of poverty may develop, "weak or anxious attachments" with their parents as infants which result in "full-blown insecurity during the early childhood years" (p. 15).

Jensen (2009) noted that parents living in poverty are less likely to know their children's teachers' or friends' names or to be regularly involved in school activities. He explained that frequently, families in poverty are overstressed about the financial impact on their families and that leads to "insufficient nurturing, disengaged parenting, and difficulty focusing on the needs of children" (p. 24). As a result, the students of low income families are exposed to more stresses than students who are not living in poverty.

Lareau (2013) discovered that while all the parents wanted their child to succeed, which often meant entrance to college, the parents' ability to help their children to navigate through school, including into college, was entirely different in families of low income/poor versus higher income families. The families with lower income/poor families, had less "information about how institutions, including schools function." Further, the families "knew little about the transition from high school to college" (p. 286).

Iceland (2013) took a different approach to reporting the commonalities of families living in poverty. He reviewed poverty rates from 19592011 and compared those living in poverty to those not living in poverty. During this time, he found that the poverty rate for the elderly became very high in 1959, a rate of $35.2 \%$. However, by the late 1990's the poverty rate had dropped and become equal to that of adults 18 to 64 . By 2011, the poverty rates of the elderly had dropped to $8.7 \%$, much lower than adults in the 18 to 64 age range. Conversely, poverty rates of children, which declined from 1959 to 1973, have risen. In 2011, 21.9\% of children were poor, a higher rate than any other group is.

When considering American households, Iceland (2013) noted that in $2009,41 \%$ of people in poor households owned their homes and almost $75 \%$ owned automobiles. This is in contrast to $68 \%$ of all families owning houses and $92 \%$ of all families owning an automobile. Iceland reported that most people, poor or not, owned refrigerators, telephones, 
microwaves and televisions. However, nearly half of the poor did not own a personal computer or have internet access at home. Iceland explained that poverty in the United States is simply different from poverty in other countries because it is possible to get a used television at a store or through online communities inexpensively (p. 46). Iceland further explains that in the United States, those who do not have access to a car, are more likely to have difficulty finding and maintaining a job.

Iceland (2013) discussed the high levels of stress that poor families experience in their daily lives. This included the stress of paying bills or meeting basic needs. This stress can hinder children's development (p. 49). In addition, Iceland explained that this stress often affects parenting and marital relationships. As a result, the parents often become more punitive in their discipline less "nurturing and stimulating" (p. 50). He wrote, "This hampers children's socio-emotional, physical, cognitive, and academic development, which in turn increases their likelihood of becoming poor as adults" (p. 50).

Jensen (2009) echoed the concerns that Iceland put forth and explained that families of poverty experience many risk factors including emotional and social challenges, acute and chronic stressors, cognitive lags and health and safety issues. However, he explained the combination of risk factors is what makes daily living difficult for families of poverty. "In other words, one problem created by poverty begets another, which in turn contributes to another, leading to a seemingly endless cascade of deleterious consequences" (p. 7).

The next theme that emerged from the readings is the impact of poverty on children in schools. Jensen (2009) explained that relationships that are "strong and secure" will "help stabilize children's behavior and provide the core guidance needed to build lifelong social skills" (p. 17). However, he noted that students in poverty are less likely to learn strong social skills resulting in problems with regulating their emotions and have difficulty working in cooperative groups both of which makes them more at risk for academic and behavioral challenges in school. He explained that students raised in poverty are more likely to demonstrate the following behaviors: "acting-out behaviors, impatience and impulsivity, gaps in politeness and social graces, a more limited range of behavioral responses, inappropriate emotional responses and less empathy 
for others' misfortunes" (p. 19). These behaviors are more likely to be problematic for teachers; but Jensen noted it is important for teachers to refrain from becoming upset and instead teach them proper behaviors or responses. Jensen also noted that in low-achieving schools, students are more likely to feel "a sense of alienation. "

Iceland (2013) reported similar information. Because of stressors on families, "poor children may be more likely to act out in school, receive poor grades, and ultimately drop out of school" (p. 50).

Attendance, which has been linked to graduation rates, is also a common problem for students of poverty. Jensen (2009) explained that students of poverty often have higher rates of tardiness and absenteeism due to problems with, "transportation, health care, and family care" (p. 10). Students with attendance problems are more likely to drop out of school.

The final theme that emerged from the readings was the life long effects of poverty on children. Lareau (2013) followed up her study ten years later. She completed a follow up of each of the families. One discovery was the advantage that the families of middle-class children could offer their children that working class and poor could not. This occurred as the children were moving into the working world. Middle income families were able to use their own social networks to connect their children to opportunities. The children who grew up in workingclass and poor families did not have parents with connections which could be used to the children's advantage to get higher-paying jobs or internships. The parents of the other children often tried to help, but the doors they opened were to jobs cleaning houses, working in a restaurant as a bus boy, or painting houses.

Lareau (2013) wrote about the differences in how the children of low income/poor families understood the financial difficulties their parents faced. She wrote the young adults, "showed a striking awareness of the sacrifices their parents had made on their behalf" (p. 304). She discovered that some of the children were working in order to help their parents financially. She described this contrast, "while middle-class parents were transferring economic resources to their young adults, the workingclass and poor young adults were often transferring resources to their parents" (p. 305). In other words, the young adults entered the world 
with not only the "financial monkey of their own lives" on their backs, but also the financial monkey of their parents on their backs.

Naturally, Lareau (2013) found that students who grew up in a middle class family still had difficulties; but she wrote, "Overall, though, I find that the importance of social class did persist" (p. 264).

Lareau (2013) concluded that all the parents wanted their children to be successful but there are inequalities in what the parents can offer. She wrote,

As much as the working-class and poor parents loved their children, not one of them was able to set their child firmly on the road to a college degree, the foundation of stable and lucrative employment. These parents were swimming against the tide. Among the girls' and boys' I studied, crucial pieces of the puzzle were already in place by the time they were ten years old, making it likely that they would end up in situations similar to those of their parents-and most did so. It is not impossible for individuals to significantly change their life position, but it is not common. (Lareau, 2013, p. 343)

Lareau (2013) explained that while there are some students from working class or poor families who went to college and changed the trajectory of their financial life, those students were not the norm, they were "variations," as she called them. She wrote, "As the lives of the families in Unequal Childhoods show, social class origins have effects that are powerful and long lasting" (p. 311).

Iceland (2013) reported that getting out of poverty is not easy. He wrote, "because a child's economic position relative to others in society is so heavily influenced by that of his or her parents, 42 percent of children born to parents in the bottom fifth of the income distribution remained at the bottom" (p. 49). Thus, overcoming poverty is extremely difficult for poor children because they start their lives so far behind financially.

Iceland (2013) offered some hope, however, for families, explaining that parents can have a strong impact on their children. If the parents' value doing well in school, spend time and money investing in their 
children's lives by reading to them, buying them books, paying for quality daycare or buying a house in a safe neighborhood with good schools, this can "help children learn, maintain good health, obtain a good education and avoid poverty as adults" (p. 50).

\section{Annie's Story}

The context of Annie's story is Nebraska. As the review of literature has shown, poverty clearly exists in the United States. According to the Kids Count (n.d.) website, in Nebraska, almost one in five children live in poverty, including almost one in five children under the age of five. More than $40 \%$ of school-aged, public school children meet the poverty standard. Just under $25 \%$ of low-income working families have children and $13 \%$ of women are living in poverty in Nebraska.

Growing up, Annie struggled to understand how poor her family was. They were not homeless. They had a house. They did not live in a car but drove cars. She knew she was not "homeless poor;" but she knew their financial ability was very different than that of most of the people she knew.

Annie was the oldest of three children. Her mother had a high school diploma. Much later in life, her mother earned an associates degree. Her father had an associate's degree. Annie's mother stayed at home with the children. Annie's dad had a "relatively good job" until she was about 12 years old. At that time, the company where he worked closed. For the next several years, he changed jobs frequently, sometimes going with out work, until he could find a long term-job again. When Annie was 13, her youngest sibling entered kindergarten. Therefore, her mom began working two part-time jobs to help the family make ends meet.

One of Annie's earliest memories was of her parents telling her she would go to college. Her parents both came from big families. To illustrate the importance of college, they compared two of her cousins asking her which one did she think went to college. They explained how the two cousins were going to have dramatically different lives based on the income they would be able to generate. The idea of college was a source of hope for Annie. Although she was too young to understand what it all 
meant, she believed from that moment on that she would go to college if that were what it would take to make her financial life better. Annie was determined to have a life where she could independently take care of herself and her family.

Annie's family could not afford many extras. Their inability to purchase things was especially evident when it was time to go school shopping. When Annie was very young, she did not realize that school shopping was different for other families. However, by $2^{\text {nd }}$ or $3^{\text {rd }}$ grade, Annie had begun to realize that whatever was purchased for her at the beginning of the year had to last her all year: notebooks, pens and pencils. She knew, whenever possible, they needed to last into the next school year too.

When she was in elementary school, she got a new pair of shoes at the beginning of the year. They had to last the entire year. Annie knew this and tried to take especially good care of her shoes so they would still look nice in May. When Annie was in $7^{\text {th }}$ grade, her parents could not afford a winter coat for her. She wore a light jacket to school all year. Nebraska winters can be very cold. The jacket did not offer much warmth.

Annie was embarrassed and angry because she needed a coat and her family could not afford one. She did not want to make her parents feel bad, so she did not say anything to them. However, Annie started to realize she needed to be strategic so that this never happened to her again. She planned to ask for a winter coat for Christmas or her birthday. Then she started to plan asking for gifts based on her future needs. For example, she knew she would need shoes to play volleyball or shoes for softball, so she would ask for gifts accordingly. It was a lesson in being strategic and resourceful that she would take with her into adulthood.

Due to financial constraints, gifts were received only at Christmas and birthdays. At Christmas time, there were always comments about how they could not have certain gifts because they could not afford them. Some Christmases, there were comments about how the family would have even less that year because things were so "tight" that year. During elementary school, Annie became aware that this was not how Christmases were for everyone else.

Annie remembered feeling sad that the joys of Christmas were often intertwined with the frustration of financial limitations. She dreamed of 
being able to buy the gifts her parents and siblings really wanted.

Throughout her childhood, when an appliance needed to be replaced, like a washer, dryer or refrigerator, or the home needed repairs, the family stress was high. There were no savings to help pay for the cost of the repair or replacement. Instead, a choice would have to be made about how to pay the bills. For example, should they pay for the new refrigerator or pay the light bill and car license. It was a battle of "robbing Peter to pay Paul" and sacrificing as much as possible until eventually they could be caught up again, or caught up enough.

When their very old cars needed repairs, Annie's dad, and sometimes his friends, would work on the cars at night until they got them running again. When the cars had been fixed and fixed and fixed until they could not be fixed anymore, usually they would buy another older car from a friend who did not want the car anymore, probably because it needed some work. There was never a time that Annie's family bought a car that was fully functional at the time they bought it.

There was one particular time when the house taxes were due and there was no money for the taxes. The family had been saving for as long as they could but having enough come tax time did not look possible. For months, the family was worried they would lose their house. Somehow, they made it, but that fear was a fear Annie would never forget.

Annie would feel very scared during times like this. She was afraid her parents would lose their house and they would have no place to live. She was scared they would not have working cars; or they would be somewhere and their cars would break down. They would not be able to afford the repairs. She was overwhelmed by how they would be able to pay their bills and scared of what would happen if they could not. This fear made Annie determined to have a better life for herself and her future children. She did not want them to experience the same fears she did.

There were also many times during Annie's life that she would come home and the electricity would be shut off or the telephone would be disconnected because they had skipped so many months and had fallen so far behind on the bills. When Annie was younger, the family made a joke of it laughing about how their mom had forgotten to pay the bill and how forgetful she was. As Annie got older and became aware this 
was not something that happened to others, she was embarrassed and angry that this would happen to her family so often. There were many times when she would need to contact her parents; but the phone was disconnected so she would have to call the neighbors and ask them to give her parents a message.

Annie's father had many heart problems. He would end up in the hospital many times. The hospital bills were overwhelming to the family. It always felt to Annie that when things were starting to become less stressful, all of a sudden he would end up in the hospital again.

When Annie was 12, she got glasses. She had probably needed them for a year; but the family could not afford them. She was very athletic. Glasses were difficult to wear when playing sports. She always felt very different because she had glasses. One day Annie was getting ready for a softball game. She took off her glasses and sat them on the bed while she got dressed. A few minutes later, she had forgotten about her glasses and jumped on to her bed to put on her socks, excited about her upcoming softball game. She crushed her glasses and broke into tears fearful that she would not be able to play because she would not be able to see and the family could not afford to get them fixed. She was upset with herself that she had caused her family a financial hardship because she was careless.

Every year she begged her parents to let her get contacts. They refused year-after-year, even though Annie felt ridiculous wearing glasses. There were multiple times, the glass would break when she was playing sports. Her parents were afraid contacts would cost more, so they would not let her get them. She was not able to get contacts until the spring of her sophomore year in high school. This was an example of a time when their lack of information about contacts interfered with meeting Annie's needs.

When she was a teenager, she needed braces. Her family could not afford braces so she did not get braces until she was almost 40 years old and could pay for them herself.

One situation involved Annie's brother that was very upsetting and affected her development. When Annie's brother was four, he had three cavities in the back of his mouth. When he would open his mouth, Annie could see the teeth rotting in the back of his mouth. She asked him 
if his teeth hurt. He would report that they did not. It was hard for her to believe they did not hurt; but she was thankful they did not. When she got frustrated and asked her mom why she would not just take her brother to the dentist, her mother explained they could not afford it.

This became a recurring theme in their lives. Whenever Annie or anyone else was sick, they rarely went to the doctor because they could not afford it. Instead, the family would take as many vitamins as they could, rest and hope to feel better. Luckily, there were never significant illnesses.

The family never went without food. However, the kinds and amounts of food were limited. Most meals involved pasta, rice or something with hamburger. The cost of fresh fruit was too high. It was very, very rare to have fresh fruit. It was very rare for the family to "eat out." The only times they would eat out was if there was a relative who came from out of town and took them out to dinner. Even then, it was rare, happening only a handful of times.

At one point, the public schools started offering lunch during the summer. This was a big deal to Annie and her siblings. They could go to school during the summer to have lunch. Eventually Annie realized most kids were not doing this. Once again, she felt different.

When Annie got older, she started dating someone whose family was middle class. They would often invite her over to dinner. By her junior year, she ate almost every meal there during the week. They had fresh fruit almost every night and food other than hamburger! It was like a vacation every night. It helped her family by having one less person to feed.

Annie was very athletic. When she turned 13 , she was asked to play on a select, travelling softball team. This was the first time Annie felt recognized and special for something. Although it was a financial burden for the family, they made sacrifices to make it work. Since her family could not afford to travel with the team very often, she was given a very limited amount of money to pay for her food while she was gone. When the money was gone, she could not eat anymore. When other people chose to buy extra snacks or extra souvenirs, she often could not. If she spent money on these items, she would not have sufficient money for food. 
When Annie was 14, she started umpiring softball games to earn extra money to help pay for select softball. Annie's working career started at that point. She had at least one part-time job from that point on in her life to take as many financial burdens off her parents as she could.

Thankfully, public education offered Annie and her siblings free and reduced priced lunches. They did not always have breakfast; but they always had lunch. However, as Annie got older, there was a stigma associated with eating lunch at school. Instead, the kids would eat from the snack bar, where free and reduced lunches did not work. Therefore, Annie stopped eating school lunches, which meant most days she did not have lunch. Annie knew it was a stupid thing to do; but she felt so different from her peers. She could not wear the clothes they wore or drive the cars they drove. She wanted to do whatever she could to feel "normal."

There was never a teacher who said to Annie, "You can do this." or "Your life can be different" or "Have you ever thought about becoming a. ..." In fact, not one teacher, counselor or school staff member talked to Annie about college at all, even though her grades indicated she was college bound.

The only person who ever talked to Annie about college, other than her parents, was her softball coach. He would tell her that she could play softball in college and introduced her to many college coaches in her career. Those conversations were important because they reinforced what Annie's parents had told her so many years before, that she would go to college. Every conversation an adult had with her encouraging her to go to college or telling her that she could was an important conversation for Annie because it made college more and more of a reality.

College became a reality when Annie earned a softball scholarship to a division two school. She played softball, worked as much as possible and took a full class load.

Although her parents had talked to her about the importance of going to college, they had not talked about how to pay for it. Her parents had planted the seed that college would make a difference for her but that was the end of the conversation. Further, no one had talked to her about what degree to earn. She was a first generation college student and did not know what she did not know. However, in college, success begets 
success. She began to realize that she could continue her education. She proceeded to earn an Education Specialist degree in school psychology.

Annie loved her family, she has always been grateful that they helped her understand the importance of college. However, many life experiences did not occur. Annie's family did not take family vacations. They did not go to movies. They almost never went out to eat. They did not have cable or satellite.

To a degree, her life experiences were limited. In fact, had it not been for the experience of playing on a travelling softball team, she would have had very limited life experiences.

These things made her feel different; they also made her feel inadequate because she could not participate in conversations about movies or a television show on a certain channel. Rather than bring attention to herself for not having those experiences, Annie did not often engage in conversations with others. She learned the best way to fit in with others, was to not be noticed.

However, Annie's family instilled many strong values. Although the family could not afford many things, they valued reading. Most Sunday afternoons the family spent time reading. She read all the books she could, many for the second, third and fourth time. She loved to read because it gave her hope and understanding that life was different. She would get lost in books imagining herself grown up and changing her life. Annie's family taught her that hard work was necessary to make things better.

The effects of these experiences were that Annie experienced disappointment, fear and anger. These feelings have not fully left her. Most years at Christmas time, in order to try to make up for the years without presents, Annie buys all she can for her parents. When it is not a holiday, but she is with her parents or visiting her parents, she will buy everyday items, anything she can to take the financial strain off her parents.

Since Annie's children were 2 years old, they have seen a dentist twice a year. When her son was in $1^{\text {st }}$ grade, he got glasses. In $2^{\text {nd }}$ grade, he got contacts. If they are sick, they see a doctor. No matter what the cost, she is determined they will never feel differently because their medical needs cannot be met. 
When it is time to buy new appliances or new cars, or even when the house tax bill comes to her house, Annie immediately has a reaction of fear. Even though she and her husband are capable of finding a way to buy a new appliance, car or pay the house tax when they need to, her immediate reaction is always fear. She will think, "What if we can't pay for it." "What if we buy a new car and something happens, how will we pay for it?" The sense of fear she experienced, as a child, has not gone away in those moments, even though the situation is different.

At times when she has gotten new appliances or cars, she has given her old ones to her parents. When needed, she has purchased a car for her parents, as has one of her siblings. Annie does everything she can to take the financial burden off her parents. In return, however, the financial burden is always there for Annie.

Annie has worked since she was 14. From the time she was 21-29 she had two jobs. Since the age of 29 , she has held part-time jobs in addition to working full-time at different times mostly because she felt that if she could work, she should.

Following her parents' example, Annie talks to her children about college. Unlike her parents, she also talks about various careers they could have. She also says to them, "After you graduate from high school you will go to college. After you are done with college, you will earn your doctorate." She wants her children to plan to earn their doctorates now so that when they are older, they will be more likely to seek it.

Annie learned from a young age that when you live in poverty, there is no one to count on but yourself. If you have a financial crisis or make a bad financial choice, there is no one to rescue you. She learned that she had to be strategic and that everything has monetary value.

When Annie became an adult, she thought that the hurt and fear she had experienced growing up in poverty would go away. What she found is that the financial pressures of her family followed her into adulthood. As mentioned, as an adult, she has purchased or given her parents cars and appliances. She takes them on family vacations with her family and buys whatever she can to help them financially. Annie believes that the financial needs of her parents will always be her responsibility. 
Growing up in poverty, Annie often felt different, inadequate, scared and angry. As an adult, Annie thought those feelings would just go away. They did not. She still feels the financial pressure of life, the fear of having no one to rescue her if it goes wrong, the feelings of inadequacy because no one else she knows experienced life this way, the fear of living this way again and the anger that the pressure of money, or lack thereof, just never goes away.

\section{Conclusion}

The effects of poverty are life long. As a school administrator, Annie sees students living in poverty and has empathy for their situations. Annie also hears the comments and judgments of staff working in schools who lack understanding of life in poverty. The words are hurtful to her even today. However, as Lareau wrote, we as a country, "with respect to social class inequalities ... we remain largely blind and nearly mute" (2013, p. 311).

\section{References}

Boteach, M., \& Cooper, D. (2011, August 5). What you need when you're poor. Retrieved June 28, 2014, from http://americanprogress.org/issues/ poverty/news/2011/08/05/10063/what-you-need-when-youre-poor/

Iceland, J. (2013). Poverty in America: A handbook. Berkeley, CA: University of California Press.

KIDS COUNT Data Center. (n.d.). Indicator selection. Retrieved June 28, 2014, from http://datacenter.kidscount.org/data\#NE/2/o

Jensen, E. (2009). Teaching with poverty in mind: What being poor does to kids' brains and what schools can do about it. Alexandria, VA: ASCD.

Lareau, A. (2013). Unequal childhoods: Class, race, and family life (2nd ed.). Berkeley, CA: University of California Press.

Rector, R., \& Johnson, K. (2004, January 5). The Heritage Foundation Conservative Policy Research. Retrieved June 28, 2014, from http://www. heritage.org/ 